\title{
Sobreviviendo a la COVID
}

\author{
Cynthia Lara González
}

\section{Resumen}

Abordaré esta pandemia desde tres perspectivas: como docente, enfermera en área hospitalaria y sobreviviente de la enfermedad. Al principio de la contingencia, no tenía ni la menor idea de que cómo sería ésta, pero con el paso del tiempo me di cuenta de que no se parecía a nada que hubiéramos vivido antes.

Palabras clave: covid-19, docente, enfermería, sobreviviente.

\section{SURVIVING COVID}

\section{Abstract}

The SARS-COV-2 virus pandemic has caused great damage at all contexts, including education, which has affected the protagonists (teachers and students) of the teaching-learning process, in a holistic way. In this occasion we will only explore one of them.

Keywords: covid-19, teacher, nursing, survivor. 
"Sobreviviendo a la COVID"

Cynthia Lara González

\section{Cynthia Lara Gonzalez}

cylara@uv.mx

Licenciada en Enfermería, egresada de la Facultad de Enfermería de la Universidad Veracruzana, con Maestría en Salud Publica. Actualmente se desempeña como Enfermera General, en el Instituto Mexicano del Seguro social, además de ser docente por asignatura en la Facultad de Enfermería de la Universidad Veracruzana campus Poza Rica.

Es miembro activo del Colegio de Enfermeras de Poza Rica de Hidalgo Veracruz, A.C., con recertificación como Enfermera Docente y como Licenciada en Enfermería por la Comisión Nacional de Certificación de Enfermería (CONACE), en conjunto con la Federación Mexicana de Colegios de Enfermería A.C. Pertenece al cuerpo académico Prácticas de Salud y Educación UVCA459 y a la Red Nacional de Salud y Educación.

$\mathrm{P}$ rimero, diré que abordaré el tema de esta pandemia desde tres perspectivas diferentes: desde el punto de vista docente, como enfermera al frente de la batalla con pacientes con covid-19 en aislamiento y como sobreviviente de esta enfermedad. Al inicio de esta pandemia no tenía ni la menor idea de que cómo sería, pero al pasar del tiempo me di cuenta de que esto no se parecía a nada que hubiéramos vivido antes.

Como docente tuve que adaptarme a los cambios a la manera de enseñar, de presencial a virtual. Siendo sincera, lo virtual no es lo mío, pero a pesar de todas las adversidades he de decir que ya le estoy agarrando cariño a la formación virtual, todo con altas y bajas, pues en realidad no estamos preparados aún para esta nueva normalidad. Los estudiantes están preocupados, algunos estresados porque no cuentan con lo necesario, como internet de calidad, que les permita estar conectados a las clases. Y ellos no son los únicos, ya que yo estaba igual, tratando a marchas forzadas de crear contenido para subirlo a las plataformas, de las que, honestamente, tampoco tenía experiencia en su uso. Así, me vi en la necesidad de tomar cursos y aprender de lo que van las TIC, y de tratar que mi internet aguantara la subidera de trabajos.

Hoy en día, puedo decir que, poco a poco, estoy tratando de hacer lo mejor posible en mi labor docente, intentando no desesperarme y tratando de tener empatía con mis estudiantes que viven en comunidades alejadas y que en ocasiones no tienen luz, se les cae la red o se les acaban sus datos, igual que a mí. 
Como enfermera en el área hospitalaria, estamos en guerra contra una enfermedad que no vemos, pero cómo nos lastima. No puedo dejar de pensar en mis alumnos recién egresados que están siendo contratados como carne de cañón, ya que están destinados exclusivamente para área coviD. Algunos Ilegan reflejando el temor en sus ojos y al verme se acercan esperando palabras de aliento y para saber cómo funciona el servicio. Yo trato de orientarlos lo mejor que puedo, esperando que no se note el temor en mí y dándoles seguridad, esa seguridad que pierdo cada que un paciente fallece.

Como sobreviviente de esta enfermedad me siento bendecida, ya que no morí, sólo tengo secuelas no graves, que me dicen que pasarán con el tiempo. Pero yo aún sigo esperando que lleguen las secuelas que no se ven, aquellas que se están descubriendo apenas, esas que le quitaron la vida a mi padre, que sobrevivió a la covid atendida en casa. Al regresar a trabajar ya no pude ver que la enfermedad no lo había dejado del todo, que había hecho daño en su riñón y que tenía un edema pulmonar agudo, casi tres meses después de una recuperación exitosa a la covid-19.

Ahora, tengo que seguir adelante y ser fuerte porque el miedo a enfermar de nuevo y morir no me abandona. Tengo que volver a entrar al área covid porque es mi trabajo, porque amo mi profesión y porque necesito seguir enseñando a mis estudiantes. Porque ellos tienen que aprender que los pacientes en aislamiento por la covid sólo nos tiene al nosotros, el personal de enfermería, para poder ayudarlos, que sus vidas están en nuestras manos.

\section{Cómo CITAR ESTE ARTículo}

* Lara Gonzalez, Cynthia. (2021, enero-febrero). Sobreviviendo a la covid. Revista Digital Universitaria (RDU), 22(1). Dol: http://doi.org/10.22201/ cuaieed.16076079e.2021.22.1.14 